\title{
Chronic beryllium disease
}

INSERM

\section{Source}

INSERM. (1999). Orphanet: an online rare disease and orphan drug data base. Chronic beryllium disease. ORPHA:133

Chronic beryllium disease (CBD) is a granulomatous, interstitial lung disease that occurs in individuals who develop beryllium sensitization (BeS), a cell-mediated immune response to environmental and occupational beryllium exposure. BeS precedes the lung disease that may present with chronic dry cough, fatigue, weight loss, chest pain, and increasing dyspnea. 